\title{
Role Ústavního soudu za pandemie v nouzovém stavu: aktivní hráč, nebo pasivní přihlížející?
}

\section{The Role of the Constitutional Court during the Pandemic: Active Player or Passive Bystander?}

\author{
Michal Kovalčík ${ }^{*}$
}

\begin{abstract}
Abstrakt
Clánek se zaměruje na český Ústavni soud a jeho roli v politickém systému během pandemie covidu-19, zejména pake běbem nouzovébo stavu, a odpovídá na otázku, jakou roli by mél Ústavni soud za takové situace v systému délby moci hrát. Normativnè-analytický článek na základè obecných tezí pozitivníbo konstitucionalismu a dosavadnich teorii nouzových stavio predstavije pèt mo žných prǐstupi Ústavního soudu prì pandemické situaci, z. nichž následnè vybirá ten dle autora nejvhodnèjši a prinnáš́ negativní i pozitivní divody pro akceptaci Ústavníbo soudu jakožto duiležité̉bo aktéra politickébo systému pri zuládánípandemie.
\end{abstract}

\section{Klíčová slova}

Ústavni soud; dèlba moci; konstitucionalismus; pandemie covidu-19; nouzový stav.

\begin{abstract}
The article focuses on the Czech Constitutional Court and its role in the political system during the COVID-19 pandemic, especially in respect of state of emergency, and clarifies what role the Constitutional Court should play in the separation of power. Based on general premises of positive constitutionalism and theories of emergencies, the normative-analytical article designs five possible approaches of the Constitutional Court in a pandemic situation. Accordingly, it provides negative and positive reasons for accepting the Constitutional Court as an important player in the political system in managing a pandemic.
\end{abstract}

\section{Keywords}

Constitutional Court; Separation of Power; Constitutionalism; COVID-19 Pandemic; State of Emergency.

\section{Úvod}

Když Giorgio Agamben ve své monografii z roku 2005 prohlásil, že výjimečné stavy znamenají jednu z největších výzev pro současnou ústavní teorii či veřejné právo, ${ }^{1}$ ještě netušil, nakolik bude jeho výrok o patnáct let později aktuální. Globální pandemie covidu-19 vyvolává po celém světě otázky nejen epidemiologické či zdravotnické, ale také právní. Vlády demokratické i autoritářské, pravicové i levicové, silné i slabé vyhlásily v různých obdobách nouzový stav a setrvale vydávají, obnovují nebo pozměňují opatření ve formě

\footnotetext{
* Michal Kovalč́k, student, Právnická fakulta, Masarykova univerzita, Brno; Fakulta sociálních studií, Masarykova univerzita, Brno / Student, Faculty of Law, Masaryk University, Brno, Czech Republic; Faculty of Social Studies, Masaryk University, Brno, Czech Republic / E-mail: michalkovalcik@mail.muni.cz

1 AGAMBEN, Giorgio. State of Exception. Přel. Kevin Attell. Chicago: University of Chicago Press, 2005, s. 1.
} 
zákazů a př́kazů s cílem zabránit šíření nakažlivé nemoci. Většina opatření přitom zasahuje do základních lidských práv jednotlivců a ve fungujících liberálně demokratických režimech vyžaduje určitou míru kontroly. Narůstající moc exekutivy (executive aggrandizement) ${ }^{2}$ představuje výzvu pro ostatní složky státní moci, tedy zákonodárnou a soudní, ale současně také pro nestátní sektor - média a občanskou společnost.

Důležitým aktérem i v době pandemie mohou být i ústavní soudy, které disponují pravomocí ve větši či menší míře přezkoumávat jednotlivé exekutivní akty prizmatem ústavně chráněných hodnot, jakými jsou základní práva nebo právní stát. V tomto článku se zaměřím český Ústavní soud a jeho roli v politickém systému v čase koronakrize, zejména pak během nouzového stavu. Závěry budou nicméně v závislosti na míře shodnosti právního uspořádání aplikovatelné i na ústavní tribunály jiných zemí. Zároveň, přestože nouzový stav již v Česku od dubna 2021 pominul, nelze vyloučit, že otázka jeho fungování v souvislosti s pandemií bude dříve či později opět velmi zásadním ústavněprávním tématem - tím spíše, když účinnost pandemického zákona, představujícího jakýsi mezistupeň mezi normalitou a nouzovým stavem, skončí koncem února $2022 .{ }^{3}$

Článek odpoví na otázku, jakou roli by měl Ústavní soud v systému dělby moci za takové situace hrát, tedy do jaké míry by měl prri interakci s exekutivou a legislativou zasahovat, či nezasahovat do procesu vypořádávání se s pandemií a otázek s tímto procesem souvisejících. Jinými slovy půjde o to, zda si má Ústavní soud spíše obléci zbroj a vyčkat v Blaníku př́ípadně až do chvíle, kdy bude demokratickému právnímu státu nejhưře, či zda je lépe vyjet plnou parou vpřed a na každé zastávce pod lupou a s ústavou po ruce posuzovat kdejaký vládní krok, k jehož přezkoumání někdo vyzve.

Budu argumentovat pro aktivní přistup ústavního soudu za pandemie, nebot' takový postoj, jak popíšu, může nejen zamezit zneužití moci a nepřipustit porušování základních práv, ale také prrispěje ke zvýšení legitimity přezkoumaných kroků, zlepšení kvality budoucích opatření a snadnějšího návratu do normality. ${ }^{4}$

Článek rozvíjí závěry předestřené $\mathrm{v}$ dosavadních statích věnujícím se tomuto tématu, oproti nim přitom přináší detailnější zaměření na ústavní soudnictví, vymezuje pět základních př́stupư ústavních soudů při pandemii a předkládá argumenty pro ten nejvhodnější.

2 Srov. KHAITAN, Tarunabh. Executive aggrandizement in established democracies: A crisis of liberal democratic constitutionalism. International Journal of Constitutional Law [online]. 2019, roč. 17, č. 1. DOI: https://doi.org/10.1093/icon/moz018; a PETROV, Jan. The COVID-19 Emergency in the Age of executive Aggrandizement: What Role for Legislative and Judicial Checks? The Theory and Practice of Legislation [online]. 2020, roč. 8, č. 1-2, s. 72.

3 Viz \ 22 zákona č. 94/2021 Sb., o zákon o mimořádných opatřeních při epidemii onemocnění COVID-19 a o změně některých souvisejících zákonů.

4 K normalitě blíže ONDŘEJEK, Pavel. In: BÍLKOVÁ, Veronika, Jan KYSELA a Pavel ŠTURMA (eds.). Vyjimečné stavy a lidská práva. Praha: Auditorium, 2016, s. 56; PETROV, Jan. The COVID-19 Emergency in the Age of executive Aggrandizement: What Role for Legislative and Judicial Checks? The Theory and Practice of Legislation [online]. 2020, roč. 8, č. 1-2, s. 73. DOI: https://doi.org/10.1080/20508840.2020.1788232 
Text je normativně-analytický. V první části uvedu kontext nouzového stavu v důsledku pandemie covidu-19 v Česku a stručně shrnu klíčové rozhodnutí Ústavního soudu Pl. ÚS $8 / 20,{ }^{5} \mathrm{~V}$ němž plénum formovalo výchozí přístup, který byl později následován $\mathrm{v}$ dalších rozhodnutích. ${ }^{6}$ To proto, aby bylo zrejejmé, v jakém právním rámci se pohybujeme a především že možností, jaký právní názor k některým otázkám zvolit, existuje více a výběr té nejlepší se skrývá právě za obecnějším pohledem na to, jakou má za pandemické situace hrát Ústavní soud roli. Navážu na to ve druhé a třetí části, které tvoří jádro celého článku. Ve druhé části nejprve představím obecná východiska, na nichž stavím celou argumentaci a následně formuluji oněch pět základních př́stupů ústavních soudů při pandemii. Nakonec ve třetí části objasním ten podle mého ideální přístup, jaký by měl Ústavní soud jakožto důležitý aktér politického systému zaujmout k úspěšnému zvládnutí pandemie.

\section{Pandemický nouzový stav v Česku}

Ačkoliv pandemie takto globálních rozměrů nemá v historii moderních demokratických právních států obdoby, ${ }^{7} z$ konstitucionalistického pohledu jde o výjimečný stav či stav nouze, ${ }^{8}$ který je spjat s otázkou fungováním liberálních států již od prvopočátku. John Locke zastával názor, že vláda musí při výjimečných situacích disponovat prerogativou, právně neomezenou mocí jednat pro veřejné blaho, a to někdy i proti právu. ${ }^{9} \mathrm{Na}$ to pak navazuje Carl Schmitt se slavným výrokem: „Suverén je ten, kdo roz̧oduje o výjimečném stavu. " ${ }^{10}$ Podle Schmitta suverén tedy při výjimečném stavu nejen že vládne neomezeně, ale stává se také tím, kdo rozhoduje, že zde vůbec výjimečná situace existuje. ${ }^{11}$ Tento př́stup označujeme jako extralegální a v současné ústavní teorii i praxi je víceméně překonán př́stupem legálním. ${ }^{12}$

5 Usnesení Ústavního soudu ze dne 22. 4. 2020, sp. zn. Pl. ÚS 8/20.

6 Srov. např. usnesení Ústavního soudu ze dne 15. 12. 2020, sp. zn. Pl. ÚS 111/20, ze dne 3. 11. 2020, sp. zn. 99/20, ze dne 9. 6. 2020, sp. zn. Pl. ÚS 25/20.

7 Srov. např. SACHS, Jeffrey D. COVID-19 and Multilateralism. Horizons: Journal of International Relations and Sustainable Development, 2020, č. 16, s. 30.

8 V této obecnější části textu používám pojmy výjimečný stav, stav nouze či krizový stav jako synonyma pro určitou faktickou, nenadálou, krizovou situaci, jako jsou války, ohrožení státu, prrírodní katastrofy nebo pandemie. $V$ části věnující se české úpravě již tyto pojmy rozlišuji tak, jak je rozlišuje český ústavní pořádek.

9 LOCKE, John. Drubé pojednání o vládé. 2. vyd. Přel. Josef Král. Praha: Svoboda, 1992, s. 125-126. Filozofické dědictví.

10 SCHMITT, Carl. Politická theologie: čtyřri kapitoly ke učení o suverenitě. 1. vyd. Přel. Jan Kranát a Otakar Vochoč. Praha: Oikoymenh, 2012, s. 9, Knihovna novověké tradice a současnosti, sv. 76.

11 DYZENAHUS, David. States of Emergency. In: ROSENFELD, Michel a Andras SAJO. The Oxford Handbook of Comparative Constitutional Law. Reprint edition. Oxford: Oxford University Press, 2013, s. 444.

12 SCHEPPELE, Kim Lane. Legal and Extra Legal Emergencies. In: WHITTINGTON, Keith E., Daniel R. KELEMEN a Gregory A. CALDEIRA (eds.). The Oxford Handbook of Law and Politics. 1. vyd. Oxford: Oxford University Press, 2010, s. 165. 
Podle legálního přístupu právo ani v krizi nejde spát, ${ }^{13}$ naopak různou měrou upravuje celý krizový proces vládnutí - od procedury a způsobu vyhlášení výjimečného stavu po vydávání jednotlivých opatření při vypořádávání se s problémem. Ústava a principy dělby moci nastavují obvykle vládě limity a zároveň ji v boji s hrozbou napomáhají. ${ }^{14}$ $\mathrm{V}$ rámci tohoto přístupu lze pak ještě podle toho, která moc hraje prim, rozlišit exekutivní, legislativní a př́padně judiciální model. ${ }^{15}$

Legislativa států využívající legální cestu vypořádávání se s nouzovým stavem pak obvykle obsahuje čtyři základní prvky: (1) podmínky pro vyhlášení nouzového stavu, (2) delegaci moci, (3) limity jejího využívání a (4) ustanovení upravující judiciální či parlamentní dohled. ${ }^{16}$ Pro účely tohoto článku to nazvěme čtyrprvkeový legálníprǐstup.

Český právní řád představuje př́klad poměrně detailního legálního př́istupu $\mathrm{k}$ výjimečným stavům. Podle čl. 5 a čl. 6 ústavního zákona o bezpečnosti republiky ${ }^{17}$ může vláda vyhlásit nouzový stav v př́padě živelních pohrom, ekologických nebo průmyslových havárií, nehod nebo jiného nebezpečí, které ve značném rozsahu ohrožují životy, zdraví nebo majetkové hodnoty anebo vnitřní pořádek a bezpečnost, a to jen s uvedením důvodů na určitou dobu a pro určité území. Současně s vyhlášením musí vláda vymezit, která práva (a v jakém rozsahu) stanovená v \5 krizového zákona ${ }^{18}$ se omezujî a které povinnosti (a v jakém rozsahu) se ukládají. Vláda o vyhlášení nouzového stavu neprodleně informuje Poslaneckou sněmovnu, která jej může zrušit. V souladu s čl. 12 stejného zákona se rozhodnutí o nouzovém stavu zveřejňuje v hromadných sdělovacích prostředcích a vyhlašuje se stejně jako zákon. ${ }^{19}$

Poté, co vláda 12. března 2020 nouzový stav vyhlásila, ${ }^{20}$ začala současně vydávat i první opatření o omezení svobody pohybu, shromažd’ování, podnikání a dalších práv. Nebylo proto velkým překvapením, že první ústavní stížnosti na sebe nenechaly dlouho čekat. Pilotní rozhodnutí, které představilo výchozí př́istup Ústavního soudu k problematice krizového vládnutí a na nějž následující rozhodnutí navazovala, vydalo plénum 22. dubna 2020. Stěžovatelka (tj. fyzická osoba podle $\int 72$ odst. 1 ZÚS ${ }^{21}$ ) napadala samotné usnesení vlády o vyhlášení nouzového stavu, jednotlivá usnesení vlády

\footnotetext{
13 Srov. naopak slavný Ciceronův výrok: „Inter arma silent leges“(Ibid., s. 176).

14 Ibid., 165.

15 DYZENHAUS, David. In: ROSENFELD, Michel a Andras SAJO. The Oxford Handbook of Comparative Constitutional Law. Reprint edition. Oxford: Oxford University Press, 2013, s. 443.

16 GROGAN, Joelle. States of Emergency. Verfassungsblog [online]. 26. 5.2020 [cit. 31. 1. 2021]. Dostupné z: https://verfassungsblog.de/states-of-emergency/

17 Ústavní zákon č. 110/1998 Sb., o bezpečnosti České republiky.

18 Zákon č. 240/2000 Sb., o krizovém řízení a o změně některých zákonů (krizový zákon).

19 Srov. také již citované usnesení ÚS sp. zn. Pl. ÚS 8/20, bod 22.

20 Usnesení vlády ze dne 12. 3. 2020 č. 194, o vyhlášení nouzového stavu, zveřejněno pod č. 69/2020 Sb.

21 Zákon č. 182/1993 Sb., o Ústavním soudu.
} 
o krizových opatřeních a mimořádná opatření Ministerstva zdravotnictví na základě $\int 74$ ZÚS, přičemž tvrdila podstatný přesah svých vlastních zájmů ve smyslu $\int 75$ odst. 2 písm. a) ZÚS. ${ }^{22}$

Plénum ústavní stížnost odmítlo jako zjevně neopodstatněnou, a to z několika důvodů. ${ }^{23}$ Pro účely tohoto článku považuji za podstatné, že (1) plénum postavilo usnesení vlády o vyhlášení nouzového stavu mimo soudní přezkum, ${ }^{24}(2)$ pro svou nepříslušnost se odmítlo zabývat opatřeními, která v mezidobí pozbyla platnosti (vláda je zrušila), ${ }^{25}$ a (3) podle Ústavního soudu v daném případě stěžovatelce nešlo prominout nevyčerpání všech dostupných opravných prostředků, nebot' dostatečně netvrdila ani neprokázala podstatný přesah svých vlastních zájmů. ${ }^{26} \mathrm{~K}$ důvodu (1) je ještě třeba dodat, že ačkoliv Ústavní soud konstatoval absenci pravomoci k přezkumu vyhlášení nouzového stavu, přezkoumat by ho mohl, bylo-li by vyhlášení nouzového stavu v rozporu se základními principy demokratického právního státu a znamenalo-li by změnu podstatných náležitostí demokratického právního státu. ${ }^{27} \mathrm{~V}$ zásadě však má jít pouze o ,akt vládnutí“, politické rozhodnutí, které nepodléhá soudnímu přezkumu a kontrolu provádí pouze demokraticky zvolený politický orgán, v tomto případě Poslanecká sněmovna.

Závěry vyslovené $\mathrm{v}$ tomto usnesení (a v navazujících usneseních) byly kritizovány disentujícími soudci ${ }^{28}$ i doktrínou. ${ }^{29}$ Kupř́kladu soudkyně Tomková poukazuje na to, že i samotné vyhlášení nouzového stavu podle ní může nepřímo zasáhnout do základních práv jednotlivců. ${ }^{30}$ Doktrína zase upozorňuje na to, že samotná politická povaha

22 Usnesení ÚS sp. zn. Pl. ÚS 8/20, body 8-12.

$23 \mathrm{~K}$ podrobnější analýze přezkumu opatření viz WINTR, Jan. K ústavnosti a zákonnosti protiepidemických opatření na jaře 2020. Správní právo, 2020, roč. LIII, č. 5-6.

24 Usnesení ÚS sp. zn. Pl. ÚS 8/20, body 21-31.

25 Usnesení ÚS sp. zn. Pl. ÚS 8/20, bod 49.

26 Usnesení ÚS sp. zn. Pl. ÚS 8/20, body 59-66.

27 Je přitom otázkou, zda zásah Ústavního soudu bude možný pouze při kumulativním splnění obou popsaných podmínek, tj. vedle rozporu i změna těchto základních náležitostí, anebo postačí pouhý rozpor $\mathrm{s}$ těmito principy.

28 Srov. odlišné stanovisko Kateřiny Šimáčkové, Vojtěcha Šimíčka a Davida Uhlíře k výroku i odůvodnění usnesení ÚS sp. zn. Pl. ÚS 8/20; odlišné stanovisko Milady Tomkové k odůvodnění usnesení ÚS sp. zn. Pl. ÚS 8/20; či odlišná stanoviska soudkyně Milady Tomkové a soudců Jana Filipa, Jaroslava Fenyka, Radovana Suchánka a Josefa Fialy k usnesení ÚS ze dne 16. 3. 2021, sp. zn. Pl. ÚS 12/21.

29 Viz např. VIKARSKÁ, Zuzana. Czechs and Balances - One Year Later. Verfassungsblog [online]. 2021 [cit. 31. 1. 2021]. Dostupné z: https://verfassungsblog.de/czechs-and-balances-one-year-later/; Role Ústavního soudu v koronakrizi. Jurisprudence, 2021, roč. 2021, č. 2; WINTR, Jan. K ústavnosti a zákonnosti protiepidemických opatření na jaře 2020. Správní právo, 2020, roč. LIII, č. 5-6; HORÁK, Filip, Jakub DIENSTBIER a Viktor DERKA. Právní úprava mimořádného vládnutí v kontextu pandemie covid-19. Rozhodnutí o vyhlášení nouzového stavu. Právník, 2021, roč. 160, č. 6.

30 Odlišné stanovisko Milady Tomkové k odůvodnění usnesení ÚS sp. zn. Pl. ÚS 8/20. 
vyhlášení nouzového stavu nevylučuje soudní přezkum ${ }^{31}$ a Horák, Dienstbier a Derka ${ }^{32}$ stejně jako Chvojka ${ }^{33}$ prripomínají, že kontrola vlády Poslaneckou sněmovnou je v systému parlamentní demokracie velmi omezená, nebot' se vláda zpravidla opírá o většinu (at’ už explicitní, či tichou) v Poslanecké sněmovně, potřebnou pro její existenci. Podle soudců Šimíčka, Šimáčkové a Uhlíře navíc v daném př́padě byly splněny podmínky pro konstatování podstatného přesahu vlastních zájmů stěžovatelky. ${ }^{34}$

Odlišná stanoviska se potom $\mathrm{v}$ různých proměnách opakovala i při následných rozhodnutích vycházejících z tohoto pilotního usnesení, ${ }^{35} \mathrm{v}$ nichž se začaly ukazovat nedostatky nastaveného př́stupu. V usnesení Pl. ÚS 12/21 ze 16. března 2021 plénum setrvalo na názorech z pilotního usnesení a konstatovalo absenci pravomoci k přezkoumávání vyhlášení nouzového stavu, aby ho však následně pod clonou (prý) obiter dicta za neústavní „nezávazně“ prohlásilo. ${ }^{36}$ Diverzita právních názorů a problematičnost přístupu ÚS se do jisté míry projevovala i v rozhodnutích správních soudů. ${ }^{37}$ Třeba Městský soud v Praze si při rozhodování o opatření, jež zakazovalo kontaktní výuku mimo jiné i na jednom z pražských gymnázií, sám ústavnost opatření jako prejudiciální otázku posoudil. ${ }^{38}$ Došlo tak k paradoxní situaci, kdy Ústavní soud pravomoc k přezkoumání vyhlášení nouzového stavu vůbec neměl, obecný prvoinstanční správní soud už ale fakticky ano.

Analýza citovaného usnesení ani navazující judikatury však nepředstavuje podstatu tohoto článku. ${ }^{39}$ Smyslem této pasáže je upozornit na to, že možností, jaký právní názor k předestřeným otázkám zvolit, existuje více a výběr té nejlepší se skrývá právě za obecnějším pohledem na to, jakou má za pandemické situace hrát Ústavní soud roli. Následující části článku se tento obecnější pohled pokusí předestřít. Dříve než objasním ideální prrístup, předložím ve druhé části textu obecná východiska, na nichž moji argumentaci stavím.

31 VIKARSKÁ, Zuzana. Czechs and Balances - If the Epidemiological Situation Allows... Verfassungsblog [online]. 2020 [cit. 31. 1. 2021]. Dostupné z: https://verfassungsblog.de/czechs-and-balances-if-the -epidemiological-situation-allows/

32 HORÁK, Filip, Jakub DIENSTBIER a Viktor DERKA. Právní úprava mimořádného vládnutí v kontextu pandemie covid-19. Rozhodnutí o vyhlášení nouzového stavu. Právník, 2021, roč. 160, č. 6.

33 CHVOJKA, Šimon. Role Ústavního soudu v koronakrizi. Jurisprudence, 2021, roč. 2021, č. 2, s. 16.

34 Odlišné stanovisko Kateřiny Šimáčkové, Vojtěcha Šimíčka a Davida Uhlî̌re k výroku i odůvodnění usnesení ÚS sp. zn. Pl. ÚS 8/20.

35 Srov. např. odlišná stanoviska soudkyně Milady Tomkové a soudců Jana Filipa, Jaroslava Fenyka, Radovana Suchánka a Josefa Fialy k usnesení ÚS ze dne 16. 3. 2021, sp. zn. Pl. ÚS 12/21.

36 Usnesení ÚS sp. zn. Pl. ÚS 8/20, bod 22. Šlo o přezkoumání vyhlášení nouzového stavu, který vláda vyhlásila - přes vyjádření nesouhlasu Poslanecké sněmovny s prodloužením - na žádost hejtmanů.

37 Srov. např. rozsudek Městského soudu v Praze ze dne 23. 2. 2021, č. j. 17 A 126/2020-84, rozsudek Nejvyššího správního soudu ze dne 26. 2. 2021, č. j. 6 As 114/2020-6.

38 Rozsudek Městského soudu v Praze ze dne 23. 2. 2021, č. j. 17 A 126/2020-84.

39 To už ostatně učinili jiní - viz např. CHVOJKA, Šimon. Role Ústavního soudu v koronakrizi. Jurisprudence, 2021, roč. 2021, č. 2; HORÁK, Filip, Jakub DIENSTBIER a Viktor DERKA. Právní úprava mimořádného vládnutí v kontextu pandemie covid-19. Rozhodnutí o vyhlášení nouzového stavu. Prámník, 2021, roč. 160, č. 6. 


\section{Pět možných př́stupů ústavních soudů v pandemii}

Blaho či snad výstižněji well-being všech občanů vytváří podle Nicka Barbera hlavní cíl státu a zajištění tohoto cíle hlavní účel státu. ${ }^{40}$ Zkonkretizujeme-li tento cíl na pandemickou situaci, lze well-being všech občanů v tomto případě zhmotnit jako zastavení šíření nakažlivé nemoci při současném co nejmírnějším dopadu na ekonomiku, stejně jako na základní lidská práva. Od moderního demokratického právního státu se tak očekává, že naplní své negativní i pozitivní závazky vưči jednotlivcům. Zdrží se zásahů do jejich základních práv a bude rovněž aktivně jednat tak, aby tato práva (v této situaci především právo na ochranu života a zdravî) nebyla ohrožena někým či něčím třetím a aby mohla být v co největší míře

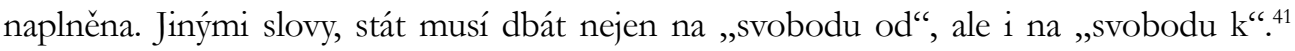
Mylný je proto pohled, že ideálem lidskoprávního počínání státu prri epidemických opatřeních by bylo nevydávat žádná omezující opatření - takový stát by totiž sice naplnil své negativní závazky, zcela by však propadl na poli závazků pozitivních. ${ }^{42}$

Je-li státní moc vykonávána prostřednictvím orgánů moci zákonodárné, výkonné a soudní, ${ }^{43}$ musí být tento cíl společný a tyto závazky plněny dohromady všemi třemi mocemi, resp. jejich orgány a aktéry. Smyslem dělby moci totiž není pouze ochrana negativní svobody, ochrana před koncentrací moci v rukou jednoho tyrana, ale také zvýšení efektivity vládnutí v širším slova smyslu tím, že se jednotlivé kompetence dělí podle toho, která moc a který orgán se jeví pro výkon takové kompetence nejvhodnějším. ${ }^{44}$ Zatímco instituce zákonodárné moci poskytují prostor pro diskuzi amatérů (ve smyslu opozita $\mathrm{k}$ expertům) mnoha různých názorových proudů a nastavují směr jednotlivých politik (policy), ${ }^{45}$ orgány exekutivy disponují širokým odborným aparátem s expertízou na konkrétní oblasti politik a očekává se od nich primárně ř́zení a činění konkrétních kroků na základě směru určeného parlamentem, včetně stanovení různých technikálií. Exekutiva zároveň jako jediná disponuje kompetencí vynutit výstupy legislativy a justice. ${ }^{46}$ Soudní moc celou triádu doplňuje a existuje $\mathrm{k}$ řešení právních sporů mezi dvěma stranami

40 BARBER, Nick. The Constitutional State. Reprint edition. Oxford: Oxford University Press, 2012, s. 56.

41 BERLIN, Isaiah. Ctyř eseje o svobodě. 1. vyd. Přel. Martin Pokorný. Praha: Prostor, 1999, s. 213-270, Střed, Sv. 27.

42 EICHLER, Jessika a Sumit SONKAR. Challenging absolute executive powers in times of corona: re-examining constitutional courts and the collective right to public contestation as instruments of institutional control. Review of Economics and Political Science, 2021.

43 Srov. čl. 2 odst. 1 Ústavy.

44 BARBER, Nicholas William. The Principles of Constitutionalism. Oxford, United Kingdom: Oxford University Press, 2018, s. 56; a HAMILTON, Alexander et al. Listy federalistio. Olomouc: Vydavatelství Univerzity Palackého, 1994, Listy 37 a 47; srov. také WALDRON, Jeremy. Constitutionalism: A Skeptical View. NYU School of Law, Public Law Research Paper No. 10-87. 2012, s. 24.

45 BARBER, Nicholas William. The Principles of Constitutionalism. Oxford, United Kingdom: Oxford University Press, 2018, s. 59.

46 Ibid., s. 66-67. 
a k interpretaci a „doladění“ platného práva. ${ }^{47}$ Jejich hlavní předností oproti jiným složkám je nestrannost a nezávislost vyžadovaná jejich společenskou funkcí. ${ }^{48} \mathrm{Ve}$ zkratce, od parlamentu čekáme amatérskou diskuzi při střetu různých zájmů, od exekutivy expertizu a manažerské schopnosti a od soudů právní dovednosti spočívající v právní znalosti, metodologii a argumentaci.

$\mathrm{V}$ nouzových stavech roste síla exekutivy a nejinak se tomu stalo také při pandemii covidu-19. Epidemiologické aspekty šíření viru a jeho dopady ve zdravotní či ekonomické oblasti vyžadují odborníky v dané oblasti a také rychlé, akceschopné rozhodovací procesy. To může v plné míře nabídnout pouze exekutiva. Jak ovšem teoreticky popisuje Petrov a empiricky potvrzuje Maerz a kol., koncentrace moci pouze v rukou exekutivy a razantní upozadění ostatních dvou složek nepřispívá k efektivnímu vypořádání se s pandemií ${ }^{49}$ a navíc hrozí, že výkonná složka v čele s lídry s autoritářskými sklony se již své moci nebude ani po opadnutí pandemie chtít vzdát. ${ }^{50}$ Ivan Krastev se svým obvyklým patosem upozorňuje: „Epidemie infikuji společnost strachem. Prestože mohou prinést to nejlepši z lidi, mohou prinést také to nejhorši z. vládnouci garnitury. "51 Svou podstatnou roli proto i v pandemické situaci musejí hrát parlamenty a soudy, nebot' obě tyto složky disponují jak negativními, tak pozitivními schopnostmi, jimiž přispějí k naplnění společného cíle státní moci. ${ }^{52}$

Jedním z aktérů $\mathrm{v}$ rámci moci soudní jsou ústavní soudy, jež setrvale přešlapují na rozhraní práva a politiky. ${ }^{53}$ Tím vlastně ideálně zapadají do situace způsobené nouzovými stavy, které vytvářejí „bod nerovnováhy mezi veřejným právem a politickým faktem“, nacházejícího se vždy na tenké a nejasné hranici mezi právem

47 BARBER, Nicholas William. The Principles of Constitutionalism. Oxford, United Kingdom: Oxford University Press, 2018, s. 60; SHAPIRO, Martin M. Courts: a comparative and political analysis. Paperback edition. Chicago: University of Chicago Press, 1986, kap. 1.

48 SHAPIRO, Martin M. Courts: a comparative and political analysis. Paperback edition. Chicago: University of Chicago Press, 1986, kap. 1.

49 MAERZ, Seraphine F. et al. Worth the Sacrifice? Illiberal and Authoritarian Practices during Covid-19. V-Dem Working Paper 110 [online]. 2020 [cit. 5. 2. 2021]. DOI: https://doi.org/10.2139/ssrn.3701720; PETROV, Jan. The COVID-19 Emergency in the Age of executive Aggrandizement: What Role for Legislative and Judicial Checks? The Theory and Practice of Legislation [online]. 2020, roč. 8, č. 1-2.

50 Srov. Orbánovo utužení hybridního režimu směrem k autoritářskému: DRINÓCZI, Tímea a Agnieszka BIEN-KACAEA. COVID-19 in Hungary and Poland: extraordinary situation and illiberal constitutionalism. The Theory and Practice of Legislation [online]. 2020, roč. 8, č. 1-2. DOI: https://doi.org/10.1080/20 508840.2020.1782109

51 KRASTEV, Ivan. Is It Tomorrow Yet?: Paradoxes of the Pandemic. B.m.: Allen Lane, 2020, s. 6. Citováno podle anglického originálu.

52 PETROV, Jan. The COVID-19 Emergency in the Age of executive Aggrandizement: What Role for Legislative and Judicial Checks? The Theory and Practice of Legislation [online]. 2020, roč. 8, č. 1-2, s. 78. Petrov v tomto článku nabízí zevrubnou analýzu vztahu mezi mocemi (s důrazem na vztah exekutivy a legislativy), s níž se ztotožňuji.

53 Srov. KYSELA, Jan. Ústava mezi právem a politikou: úvod do ústavni teorie. Praha: Leges, 2014, s. 304, Teoretik. 
a politikou. ${ }^{54}$ Pustí-li se ústavní soudy do přezkumu jednotlivých opatření, nevyhnutelně se zachází do oblasti tzv. mega-politics, tedy zásadních, a proto i mediálně exponovaných otázek s dopadem na celý politický systém a společnost. ${ }^{55}$ Mohou však zůstat také spíš v rovině přezkumu formálního, procedurálního, což lze v Hirschlově pojetí podřadit pod druhý, méně invazivní stupeň judicializace politiky (třetí stupeň jsou právě mega-politics). ${ }^{56}$ Ústavní soudy mohou tedy do pandemické krize vstupovat přezkumem: (1) kompetencí k vyhlášení nouzového stavu a vydávání opatření; (2) procedury vyhlášení nouzového stavu i přijatých opatření, přičemž tyto první dva body můžeme označit jako procedurální stránku; a (3) obsahu, tj. především souladu opatřneni se základními právy ${ }^{57}$ a vhodnosti či nezbytnosti vyhlášení nouzového stavu.

Vyjdeme-li z těchto premis, můžeme v systémech využívajících obvyklou čtyřprvkovou ${ }^{58}$ legální cestu vypořádávání se s výjimečným stavem ${ }^{59}$ formulovat pět základních možných prrístupů ústavních soudů k přezkumu samotného vyhlášení nouzového stavu a navazujících opatření: (1) žádný přezkum, (2) velká zdrženlivost, (3) zdrženlivost, (4) aktivita a (5) velká aktivita.

1. Žádný prezkeum. Ústavní soudy nepřezkoumávají ani vyhlášení ani jednotlivá opatření, nechávají vládě volnou ruku a odkazují se na kontrolu demokraticky zvoleným parlamentem.

2. Velká żdř̌enlivost. Ústavní soudy přezkoumávají opatření, a to pouze z procedurální stránky, meritem se nezabývají. Vyhlášení ponechávají mimo soudní přezkum (odpovídá druhému stupni Hirschlovy judicializace).

3. Zdrženlivost. Ústavní soudy přezkoumávají procedurální stránku opatření i vyhlášení, př́padně i zjevný rozpor s principy právního státu. ${ }^{60}$ Meritornímu přezkumu se nevěnují (odpovídá druhému až třetímu stupni judicializace).

4. Aktivita. Ústavní soudy přezkoumávají procedurální stránku vyhlášení nouzového stavu, př́padně i zjevný rozpor s principy právního státu, a zároveň posuzují i proporcionalitu jednotlivých opatření (odpovídá druhému až třetímu stupni judicializace).

54 AGAMBEN, Giorgio. State of Exception. Přel. Kevin Attell. Chicago: University of Chicago Press, 2005, S. 1.

55 HIRSCHL, Ran. The Judicialization of Politics. In: WHITTINGTON, Keith E., Daniel R. KELEMEN a Gregory A. CALDEIRA (eds.). The Oxford Handbook of Law and Politics. 1. vyd. Oxford: Oxford University Press, 2010, s. 121-124.

56 Ibid., s. 121-124. Zde poznamenávám, že popsané vnímání Hirschlových stupňủ judicializace se mírně liší od interpretace Davida Kosaře, kterou popisuje nap̌̌. v KOSAŘ, David. Judicializace justiční politikey Evropským soudem pro lidská práva. 1. vyd. Praha: Wolters Kluwer, 2016, s. 91, Právní monografie.

57 To může zahrnovat různě intenzivní testy (test racionality, test proporcionality, popř. test rovného zacházení - viz dále).

58 Podmínky vyhlášení, delegace moci, její limity a přezkum - viz první část textu.

59 Uvedené přístupy se vztahují k situaci, kdy vláda zvolí pro vypořádávání se s pandemií vyhlášení nouzového stavu.

60 Mezi principy právního státu řadím mj. i absenci libovůle. 
5. Velká aktivita. Ústavní soudy přezkoumávají meritorně jak vyhlášení nouzového stavu, tak i jednotlivých opatření. U opatření posuzují proporcionalitu (možné různě intenzivní testy - viz dále), u vyhlášení nouzového stavu alespoň jeho vhodnost a nezbytnost (řeší mega-politics v plném rozsahu).

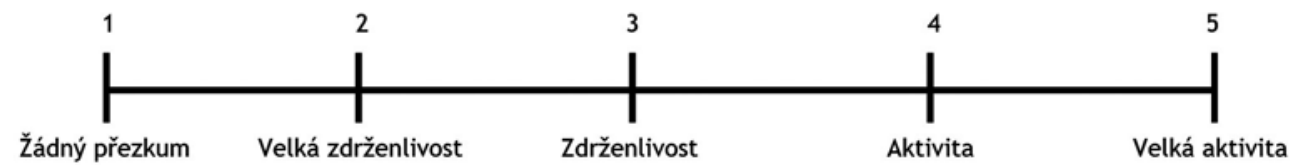

Přístup konkrétního tribunálu samozřejmě odvisí od právní úpravy $\mathrm{v}$ dané zemi a je možné je navzájem kombinovat. V České republice považuji první tři př́istupy, odmítající se bez dalšího věnovat meritornímu přezkumu jednotlivých opatření, za vyloučené. ${ }^{61}$ Listina základních práv a svobod - na rozdíl třeba od Evropské úmluvy o lidských právech $^{62}$ - neobsahuje koncept dočasného „vypnutí“ některých v ní obsažených práv, ba co víc - dokonce vyjmutí základních práv z přezkumu v čl. 36 odst. 2 výslovně zakazuje. ${ }^{63}$ „Vypnout“ pak nelze ani čl. 83 Ústavy. Z \ 5 krizového zákona potom vyplývá požadavek nezbytnosti při omezení práv co do rozsahu i doby, což nevyhnutelně implikuje soudní kontrolu. ${ }^{64}$ Navíc nepřezkoumatelnost pandemických opatření zasahujících do základních práv označila za nepřípustné také Benátská komise. ${ }^{65}$

Pro český Ústavní soud tak zůstávají v otázce přezkumu opatření akceptovatelné přístupy č. 4 a č. 5, v otázce vyhlášení nouzového stavu může jít o kterýkoliv z př́istupů. Výčet přístupů samozřejmě není vyčerpávající, především č. 4 a č. 5 by šly dále dělit podle intenzity meritorního přezkumu. V USA např́klad probíhající soudní diskurz tenduje k tzv. rational basis test, tedy testu využívající jako referenční rámec vyloučení libovůle a racionality (nižší standard než intermediate a strict scrutiny; někdy nepřesně připodobňován $\mathrm{k}$ českému testu racionality). Někteří autoři to však kritizují a nabízí revidované focused scrutiny, které bere v potaz konkrétní specifika šírící se nemoci. ${ }^{66}$ Test racionality v českém kontextu by se na první pohled vzhledem k jeho menší prúśnosti mohl

61 Ve smyslu absence pravomoci k přezkumu. Samozřejmě k samotnému posouzení musejí být naplněny zákonem stanovené požadavky, jako např. dodržení principu subsidiarity ústavní stížnosti.

62 Srov. čl. 15 této Úmluvy a blíže viz GREEN, Alan. States should declare a State of Emergency using Article 15 ECHR to confront the Coronavirus Pandemic. Strasbourg Observers [online]. 1. 4. 2020 [cit. 6. 2. 2021]. Dostupné z: https://strasbourgobservers.com/2020/04/01/states-should-declare-a-state-of-emergency-using-article-15-echr-to-confront-the-coronavirus-pandemic/

63 Čl. 36 odst. 2 in fine: „Z pravomoci soudu však nesmi být vyloučeno prę̌koumávání roz̧hodnutí týkajícich se základnich práv a svobod podle Listiny."

64 Srov. WINTR, Jan. K ústavnosti a zákonnosti protiepidemických opatření na jaře 2020. Správní právo, 2020, roč. LIII, č. 5-6, s. 291.

65 Stanovisko Benátské komise ze dne 26. 5. 2020, CDL-PI(2020)005rev, body 86-89.

66 GATTER, Robert. Reviving Focused Scrutiny in the Constitutional Review of Public Health Measures. Washington University Journal of Law and Policy, Forthcoming, Saint Louis U. Legal Studies Research Paper No. 2020-32 [online]. 2020 [cit. 6. 5. 2021]. DOI: https://doi.org/10.2139/ssrn.3690125 
zdát při pandemii vhodný, ovšem při uvážení požadavku nezbytnosti plynoucího z \5 krizového zákona bude nutné použít test proporcionality. ${ }^{67}$ Pandemická opatření navíc často zasahují samotné jádro základních práv (např. uzavření provozoven do svobody podnikánî). ${ }^{68}$

V nouzovém stavu vyhlášeném pro bezprecedentní pandemii však soudy musejí brát $\mathrm{v}$ potaz specifika výjimečné situace a nejinak tomu bude i u testu proporcionality. Přiměřenost jednotlivých opatření by měla být posuzována podle toho, co příslušným orgánům mohlo a mělo být $\mathrm{v}$ době přijetí opatření známo. ${ }^{69} \mathrm{O}$ míře nejistoty, jîž musí být přímo úměrný prostor pro uvážení rozhodujících orgánů, se zmiňuje i Ústavní soud v nálezu o zavření maloobchodů ${ }^{70}$ a stejně tak i Městský soud v Praze. ${ }^{71}$ Federico Fabbrini představil na empirických př́kladech vystavěný koncept dynamického modelu role soudů v nouzových stavech. ${ }^{72}$ Začátek krizové situace se obvykle vyznačuje nedostatkem informací a zásahy do práv trvající zatím velmi krátce, proto soudy mají být v přezkumu zdrženlivější. Trvá-li krizová situace déle, informací včetně vědeckých poznatků začíná být více a zásahy do základních práv se v důsledku prodlužující se doby stávají závažnějšími. S tím se postupně i mění role soudů z velmi zdrženlivého na aktivního aktéra. ${ }^{73}$ Tento model považuji za veskrze aplikovatelný i na roli ústavních soudů při pandemii covidu-19.

Český Ústavní soud dosud k přezkumu jednotlivých opatření přistoupil pouze jednou ve zmiňovanému nálezu o zavření maloobchodů, v němž víceméně Fabbriniho dynamický model podpořil: „Na jedné straně neni úkolem Ústavního soudu požadovat v rámci ústavněprávního prezkumu po vládè, aby nalezlla a perfektnè oduivodnila (spišse bypotetické) ,optimální rèseni" a optimálni distribuci bremen spojených s omezenim základnich práv určitých skupin obyvatel, jestliže ani mezi odborniky neexistuje na hodnoceni aktuálni situace a prognózách jejỉho možného vývoje praktické shoda (požadavek na odìvodnèni nesmi být, přehnaný). Z ústavního blediska však neni možné prípustit ani drubý extrém. Lakonicky rěreno, ani praktická nejistota a nedostatek perfektních

67 Srov. ONDŘEJEK, Pavel. Proporcionalita opatření prijij́maných ve výjimečných stavech. Cáasopisproprávní védu a praxi. Brno: Masarykova univerzita, Právnická fakulta, 2020, roč. 28, č. 4, s. 621. DOI: https:// doi.org/10.5817/CPVP2020-4-4. Dostupné z: https://journals.muni.cz/cpvp/article/view/13595; a ŠEJVL, Michal et al. Vitě̃zové a poražení: Právní a etické problémy současné koronakrize. Praha. B.m.: Ústav státu a práva AV ČR, 2020, s. 39.

68 Srov. nález ÚS ze dne 9. 2. 2021, sp. zn. Pl. ÚS 106/20, bod 54.

69 ONDŘEJEK, Pavel. Proporcionalita opatření prrijímaných ve výjimečných stavech. Časopis pro právní vědu a praxi. Brno: Masarykova univerzita, Právnická fakulta, 2020, roč. 28, č. 4, s. 624. DOI: https://doi. org/10.5817/CPVP2020-4-4. Dostupné z: https://journals.muni.cz/cpvp/article/view/13595

70 Nález ÚS ze dne 9. 2. 2021, sp. zn. Pl. ÚS 106/20, bod 76.

71 Rozsudek Městského soudu v Praze ze dne 7. 5. 2020, č. j. 10 A 35/2020-261, odst. 84.

72 FABBRINI, Federico. The role of the judiciaries in times of emergency: Judicial review of counter-terrorism measures in the US Supreme Court and the European Court of Justice. Yearbook of European Law, 2010, roč. 28, č. 1. DOI: https://doi.org/10.1093/yel/28.1.664

73 Ibid., s. 693-696. 
informaci neznamenaji, že vláda müže učinit ,cokoliv' a spoléhat se pritom pouze na instinkt či politický kompromis. Roz̧hodnuti vlády se totiž musi opírat o odborná doporučení, vycházejici z maximálni miry dostupných znalosti o dané nemoci a jejímu širení."74

Odpověd’ na otázku, jaký test k přezkumu opatření zvolit, však citovaný nález úplně jasně neprredkládá. Předně je třeba připomenout, že se nález zabýval zásahem do práva podnikat (a na rovné zacházení - viz dále) a nezabýval se tak primárně kolizí s jinými právy jako svoboda pohybu, shromažd’ování nebo práva na soukromí. Nicméně i závěry jen k tomuto konkrétnímu (sociálnímu) právu považuji ve vztahu k intenzitě přezkumu za mírně rozporné. Ústavní soud totiž nejprve konstatuje, že opatření zasahuje do samotné podstaty práva podnikat, ${ }^{75}$ což by indikovalo intenzivnější přezkum, v dalším části nálezu se však testem proporcionality nezabývá, ale kombinuje test rovnosti s jakýmsi testem racionality. V jednu chvíli totiž vyžaduje, aby opatření byla vzhledem k cíli přiměřená, ${ }^{76}$ později už postačí, aby byla rozumná („nemusí jít o řešení optimální, nejvhodnější, nejlepší‘) ${ }^{77}$ a nakonec celé nařízení zruší na základě toho, že pro nedostatek odůvodnění nelze u nerovného zacházení posoudit ani přiměřenost, ani rozumnost.

Hlavním poselstvím Ústavního soudu v tomto dosud jediném meritorním nálezu bylo tak ono „memento“ vládě požadující odůvodnění opatření a nikoliv tedy vyjasnění způsobu přezkumu krizových opatření. Přesto zde plénum naznačilo tři následující možnosti věcného přezkumu - podle stupně intenzity (1) test racionality, (2) test rovného zacházení a (3) test proporcionality. Všechny tyto postupy ve smyslu výše popsaných pěti př́stupů spadají do kategorie č. 4, prípadně i č. 5 (jde o meritorní přezkum). Podle intenzity přezkumu lze tak tyto př́istupy ještě dále analyticky dělit. Test rovného zacházení však soud použije přirozeně jen tam, kde $\mathrm{k}$ dojde $\mathrm{k}$ nějakému rozlišování.

$\mathrm{Na}$ základě výše uvedeného můžeme obecně u českého Ústavního soudu identifikovat oslabený prrístup č. 4, tedy oslabenou aktivitu. Až na výše probrané základní náležitosti demokratického právního státu plénum vyjmulo přezkum vyhlášení nouzového stavu z jeho pravomoci, což odpovídá bud' zesílenému př́stupu č. 1, nebo oslabenému č. 2, č. 3 a č. 4, jelikož se nehodlá věnovat „běžným“ procedurálním či kompetenčním nedostatkům. V otázce přezkumu opatření se pak Ústavní soud přiklonil k přístupu č. 4 či č. 5 (aktivita či velká aktivita), tedy meritorní přezkum. Na druhou stranu se plénum velmi restriktivně postavilo $\mathrm{k}$ formálním otázkám přípustnosti takové stížnosti podstatný přesah ústavní stížnosti zde byl představen jako takřka nedosažitelný institut, a navíc byla z přezkumu možná až formalisticky vyňata ta opatření, jež pozbyla platnosti. Také z těchto důvodu označuje Chvojka roli Ústavního soudu za pandemie za pasivní. ${ }^{78}$

74 Nález ÚS ze dne 9. 2. 2021, sp. zn. Pl. ÚS 106/20, bod 76.

75 Ibid., bod 54.

76 Ibid., bod 58 .

77 Ibid., bod 87.

78 CHVOJKA, Šimon. Role Ústavního soudu v koronakrizi. Jurisprudence, 2021, roč. 2021, č. 2, s. 26. 
Shrnu-li, Ústavní soud zvolil přístup, který má aspekty jak aktivního, tak zdrženlivého a velmi zdrženlivého přístupu až přístupu zcela bez soudního přezkumu.

Domnívám se však, že Ústavní soud by se měl při pandemickém přezkumu činit více a kopírovat ideálně přístup č. $4 \mathrm{v}$ plné šíri, tedy aktivní přístup (nikoliv oslabený). Takový př́stup totiž může zabránit zneužití moci, přispět $\mathrm{k}$ vyšší kvalitě opatření a jejich komunikaci a také prispět $\mathrm{k}$ větší legitimitě opatření. ${ }^{79} \mathrm{~V}$ následující části textu jednotlivé důvody podrobněji rozeberu.

\section{Aktivní Ústavní soud jako důležitý aktér $\mathrm{k}$ úspěšnému zvládnutí pandemie}

$\mathrm{V}$ předchozí části jsem vymezil pět základních př́stupů, které mohou ústavní soudy během pandemie zaujmout. V této poslední části budu argumentovat pro to, aby český Ústavní soud zastával aktivní přístup představující v mém členění č. 4. Takový přístup totiž může (1) zabránit zneužití moci, (2) přspět k vyšší kvalitě opatření a jejich komunikaci; a (3) přispět k větší legitimitě opatření. Pojd'me se nyní na jednotlivé důvody podívat ve větším detailu.

\subsection{Zabránění zneužití moci}

Soudce Jackson ve svém slavném odlišném stanovisku k rozhodnutí Nejvyššího soudu USA v kauze Korematsu proti Spojeným státuim, ${ }^{80}$ schvalujícím internaci Američanů japonského původu během 2. světové války z důvodu krizové situace, prohlásil, že jde o „nabitou z̧brañ pripravenou ke ruce jakémukoliv orgánu, který predloži vérohodné tvrzeni naléhavé potreby. "81 Takovou nabitou zbraní se (nejen) populistickým vládám stala pandemická krize, působící jako výborná záminka k upevnění moci a podle některých autorů potenciálně vedoucí až k masivnímu porušování a překreslení lokálního i globálního politického pořádku. ${ }^{82} \mathrm{Jde}$ o př́ležitost prostřednictvím nástrojů technokratických (přenesení odpovědnosti na politicky neodpovědné experty - virology či epidemiology), populistických (polarizující a nacionální rétorika, nedbání na menšiny) a antidemokratických (oslabení role parlamentů, posílení exekutivy, umlčení opozice a občanské společnosti) zneužít svou moc. ${ }^{83}$ Tyto tendence se empiricky prokazují na výzkumu 143 zemí Maerz a kol. hned v 83 státech došlo během pandemie k poklesu demokratických standardů. ${ }^{84}$

79 Srov. PETROV, Jan. The COVID-19 Emergency in the Age of executive Aggrandizement: What Role for Legislative and Judicial Checks? The Theory and Practice of Legislation [online]. 2020, roč. 8, č. 1-2, s. 80.

80 Korematsu proti Spojeným státum, 323 U.S. 214 (1944).

81 Ibid., disentní stanovisko soudce J. Jacksona.

82 EICHLER, Jessika a Sumit SONKAR. Challenging absolute executive powers in times of corona: re-examining constitutional courts and the collective right to public contestation as instruments of institutional control. Review of Economics and Political Science. 2021.

83 GUASTI, Petra. The Impact of the COVID-19 Pandemic in Central and Eastern Europe: The Rise of Autocracy and Democratic Resilience. Democratic Theory [online]. 2020, roč. 7, č. 2, s. 48. DOI: https:// doi.org/10.3167/dt.2020.070207

84 MAERZ, Seraphine F. et al. Worth the Sacrifice? Illiberal and Authoritarian Practices during Covid-19. $V$-Dem Working Paper 110 [online]. 2020 [cit. 5. 2. 2021]. Autoři zde podrobně popisují metodu výzkumu. 
Argument zabránění zneužití moci je argumentem negativního konstitucionalismu a stál u zrodu konceptu dělby moci a později také ústavního soudnictví. ${ }^{85}$ Ústavní soud by v tomto směru měl dbát na to, aby vlády nevyužívaly často vágní formulace krizových zákonů a nevládly svými dekrety i mimo problémy spojené s pandemií covidu-19 at' už věcně, či časově. ${ }^{86}$ Slovy Evropského soudu pro lidská práva, aby vládní opatření nešla za míru striktně vyžadovanou naléhavostí krize. ${ }^{87} \mathrm{~K}$ př́kladům posilnění moci nemusíme chodit daleko, Viktor Orbán v Mad’arsku během posledního roku přinejmenším razantně vykročil od hybridního režimu směrem $\mathrm{k}$ autoritářskému. ${ }^{88}$

Guasti zároveň považuje nastalou krizi také za potenciální spouštěč demokratického odporu proti autoritářskému populismu. Právě pandemie a těžkosti s ní spojené mohou paradoxně delegitimovat stávající populistické vlády. To ale vyžaduje zapojení (1) nezávislých médií zpơsobilých zpochybňovat vládní kroky a odhalovat problematická místa (to je v Mad'arsku a částečně i v Polsku problém ${ }^{89}$ ); (2) opozice a občanské společnosti, trvající na transparentnosti a schopné mobilizace občanů; a právě (3) soudů, zajišt'ujících institucionální dohled a neostýchajících se zrušit nezákonná či protiústavní opatření. ${ }^{90}$

Také v České republice se při vypořádávání se s pandemií spoléháme na populistickou vládu. ${ }^{91}$ Ústavní soud by proto společně s obecnými soudy měl zajistit to, aby taková vláda neobdržela carte blanche vedoucí v tom horším scénáři k dlouhodobému porušování základních práv. ${ }^{92}$ Zdá se, že tak - podobně jako už učinil třeba německý Spolkový ústavní soud ${ }^{93}$ -

85 Srov. BARBER, Nicholas William. The Principles of Constitutionalism. Oxford, United Kingdom: Oxford University Press, 2018, s. 19.

86 ACKERMAN, Bruce. The Emergency Constitution. The Yale Law Journal [online]. 2004, roč. 113, č. 5, s. 1081. DOI: https://www.doi.org/10.2307/4135710

87 Rozsudek ESLP ze dne 23. 7. 1968, Ireland proti Spojenému království, app. no. 5310/71, § 207, nebo rozsudek ESLP ze dne 26. 11. 1997, Sakik a dalš́ proti Turecku, app. no. 23878-23883/94, \ 44.

88 Srov. blíže DRINÓCZI, Tímea a Agnieszka BIEŃ-KACAŁA. COVID-19 in Hungary and Poland: extraordinary situation and illiberal constitutionalism. The Theory and Practice of Legislation [online]. 2020, roč. 8, č. 1-2; a GUASTI, Petra. The Impact of the COVID-19 Pandemic in Central and Eastern Europe: The Rise of Autocracy and Democratic Resilience. Democratic Theory [online]. 2020, roč. 7, č. 2, s. 51-53.

89 BÁTORFY, Attila a Ágnes URBÁN. State advertising as an instrument of transformation of the media market in Hungary. East European Politics [online]. 2020, roč. 36, č. 1. DOI: https://www.doi.org/10 .1080/21599165.2019.1662398; Srov. blíže SUROWIEC, Paweł, Magdalena KANIA-LUNDHOLM a Małgorzata WINIARSKA-BRODOWSKA. Towards illiberal conditioning? New politics of media regulations in Poland (2015-2018). East European Politics [online]. 2020, roč. 36, č. 1. DOI: https://doi. org/10.1080/21599165.2019.1608826

90 GUASTI, Petra. The Impact of the COVID-19 Pandemic in Central and Eastern Europe: The Rise of Autocracy and Democratic Resilience. Democratic Theory [online]. 2020, roč. 7, č. 2, s. 49.

91 Srov. např. HAVLÍK, Vlastimil. Technocratic Populism and Political Illiberalism in Central Europe. Problems of Post-Communism [online]. 2019, roč. 66, č. 6. DOI: https://doi.org/10.1080/10758216.2019.1580590

92 DOSWALD-BECK, Louise. Human Rights in Times of Conflict and Terrorism. B.m.: Oxford University Press, 2011, s. 70.

93 Rozhodnutí BVerfG ze dne 15. 4. 2020, sp. zn. 1 BvR 828/20, ohledně zásahu do práva shromažd’ovacího anebo rozhodnutí BVerfG ze dne 29. 4. 2020, sp. zn. 1 BvQ 44/20, týkající se náboženské svobody. 
budou činit v otázce přezkumu opatření, ${ }^{94}$ i když, jak bylo popsáno výše, odmítnutí přezkumu opatření jen pro jejich nahrazení jinými (pozdějšími, však s obdobným obsahem) vede $\mathrm{k}$ nebezpečnému precedentu, jenž se takovému bianco šeku blíží. Inspirací by zde mohl být rakouský ústavní soud, který před Vánoci zrušil již neplatná nařízení spolkového ministerstva školství k nošení roušek ve školách a k systému rotační výuky. ${ }^{95}$ Jak ve svém příspěvku upozorňuje Derka, toto rozhodnutí může mít vliv na prípadná již běžící, třeba deliktní, řízení. ${ }^{96}$ Ačkoliv česká právní úprava vyznívá striktněji, domnívám se přesto, že by $\int 67$ odst. 1 ZÚS měl Ústavní soud vzhledem k jeho roli vykládat méně formálně a více materiálně - stejné opatření prostě materiálně stále platí (i když pod jiným číslem). ${ }^{97}$ V otázce přezkumu vyhlášení nouzového stavu pak zde naopak o takový bianco šek zjevně jde, což může mimo jiné zasáhnout i do samotného přezkumu opatření - již reálným problémem se totiž ukázalo posuzování legality zásahu do základních práv opatřením postaveném na nezákonně přijatém nouzovém stavu. ${ }^{98}$

\subsection{Vyšší kvalita opatření a jejich komunikace}

Bezprecedentní pandemická situace nutí vlády k rychlým reakcím. Jednotlivé kroky bývají přijímány v časové tísni a pod tlakem nejrůznějších zájmů. Nelze se proto divit, že, eufemisticky řečeno, nebývají legislativně-technicky dokonalé a ani jejich odůvodnění nebývá dostatečné. Opatření bývá často výstupem debaty epidemiologů či virologů, nikoliv legislativních expertů. Zde ovšem právě přichází role pro soudy disponující dovednostmi a expertízou v právní oblasti. Soudci nejsou experty na epidemiologické otázky, jsou však experty na otázky právní. ${ }^{99}$ Zákonnost či ústavnost představuje jejich denní chléb. Soudní role při pandemii tak spočívá právě v pomoci vládě tato opatření zlepšit tak, aby respektovala principy právního státu ( $v$ širším slova smyslu, tj. i třeba dodržení procedury k jejímu přijetî) a neospravedlnitelně nezasahovala do základních

94 Srov. např̀ přístup popsaný (ač dosud nerealizovaný) v bodě 30 usnesení sp. zn. Pl ÚS 8/20 či rozsudek Městského soudu v Praze ze dne 7. 5. 2020, č. j. 10 A 35/2020-261.

95 Rozhodnutí rakouského Ústavního soudního dvora ze dne 10. 12. 2020, č. j. V 436/2020-15.

96 DERKA, Viktor. Několik vět k rozhodnutí rakouského Ústavního soudního dvora ze dne 10. 12. 2020, č. j. V 436/2020-15. Právo a kriz̧e [online]. 3. 1. 2021 [cit. 7. 2. 2021]. Dostupné z: https:// pravoakrize.net/nekolik-vet-k-rozhodnuti-rakouskeho-ustavniho-soudniho-dvora-ze-dne-10-12-2020-c-j-v-436-2020-15-2/

97 Ačkoliv se tento problém podle mě dá překlenout naznačeným výkladem, který by ještě nebyl contra legem (srov. také odlišné stanovisko Pavla Šámala k usnesení Ústavního soudu sp. zn. Pl. ÚS 102/20) vhodnější by bylo toto ustanovení ZÚS novelizovat třeba tak, jak to činí $\int 13$ odst. 4 tzv. pandemický zákon (č. 94/2021 Sb.). Zde je výslovně uvedeno, že při přezkumu ve správním soudnictví má soud vyslovit př́padný závěr o nezákonnosti, i když opatření pozbylo platnosti.

98 Rozsudek Městského soudu v Praze ze dne 23. 2. 2021, č. j. 17 A 126/2020-84.

99 BARBER, Nicholas William. The Principles of Constitutionalism. Oxford, United Kingdom: Oxford University Press, 2018, s. 63. 
práv. Soudy mohou také přispět k výkladu sporných opatření, k vyplnění jejich mezer a podobně. ${ }^{100}$ Mohou přispět ke stavu, kdy „bude více jasno“.

Soudní rozhodnutí se totiž sice ze své podstaty vztahují k nějakému případu z minulosti, účinky a implikace těchto verdiktů však míří především do budoucnosti. ${ }^{101}$ Judikatura může být vládě přínosná pro nastavení budoucích opatření - uvidí-li, že některá opatření neprojdou pro konkrétní nedostatky, přirozeně to vládě pomůže definovat meze opatřeních budoucích. ${ }^{102}$ A nejen meze, ale i způsob komunikace vládních kroků. V již citovaném rozhodnutí rakouský ústavní soudní dvůr zrušil opatření ministerstva školství právě pro nedostatečné zdůvodnění, vedoucí k nezákonnosti takového aktu. ${ }^{103}$ Podobně tak učinil v několika rozhodnutích i izraelský nejvyšší soud a taková rozhodnutí ve svém důsledku vedla $\mathrm{k}$ lépe odůvodněným nařízením. ${ }^{104}$ Dotan si v Izraeli všímá toho, že bez ohledu na rozhodnutí už samotný soudní proces vedl k takovým následkům. Vláda byla nucena před soudem detailně vysvětlit své kroky, což ji následně vedlo k redefinování některých politik a k jejich zkvalitnění. ${ }^{105} \mathrm{~V}$ Česku Ústavní soud sice v nálezu o uzavření maloobchodů požadoval řádné odůvodnění (a to s odkazem na i zde citovaná rozhodnutí rakouských a německých soudů), podle argumentace v tomto rozhodnutí však postačí, předloží-li vláda důvody až v rámci případného řízení před Ústavním soudem (nikoliv tedy nutně již při vydání opatřenî). ${ }^{106}$ To je další z projevů oslabeného aktivního př́istupu. Vzhledem $\mathrm{k}$ vysvětleným potenciálním pozitivním důsledkům by se přitom ve sporných situacích týkajících se př́pustnosti měl Ústavní soud přiklonit tak trochu $\mathrm{v}$ duchu principu „, pochybnostech ve prospěch př́pustnosti“ $\mathrm{k}$ přezkumu. ${ }^{107} \mathrm{Jak}$ poznamenává Wiley a Vladeck, soudní moc by tím vládu donutila plnit si své „domácí úkoly“ - tedy sdělovat nejen účely svých nařízení, ale také to, jak přesně se tato nařízení vztahují k těmto účelům. ${ }^{108}$ Jinými slovy, nejde jen o vznešené cíle, ale i o vznešené (nebo aspoň ospravedlnitelné) prostředky

100 PETROV, Jan. The COVID-19 Emergency in the Age of executive Aggrandizement: What Role for Legislative and Judicial Checks? The Theory and Practice of Legislation [online]. 2020, roč. 8, č. 1-2, s. 80.

101 BARBER, Nicholas William. The Principles of Constitutionalism. Oxford, United Kingdom: Oxford University Press, 2018, s. 62.

102 WILEY, Lindsay Freeman a Stephen I. VLADECK. Coronavirus, Civil Liberties, and the Courts: The Case Against "Suspending” Judicial Review. Harvard Law Review Forum [online]. 2020, roč. 133, č. 9, s. 195. DOI: https://doi.org/10.2139/ssrn.3585629

103 Rozhodnutí rakouského Ústavního soudního dvora ze dne 10. 12. 2020, č. j. V 436/2020-15.

104 DOTAN, Yoav. Continuous Judicial Review in Coronavirus Times. The Regulatory Review [online]. 11. 5. 2020 [cit. 5. 2. 2021]. Dostupné z: https://www.theregreview.org/2020/05/11/dotan-continuous-judicial-review-coronavirus-times/

105 Ibid.

106 Nález ÚS ze dne 9. 2. 2021, sp. zn. Pl. ÚS 106/20, body 83-84.

107 Srov. WAGNEROVÁ, Eliška (ed.). Zákon o Ústavním soudu s komentárem. 1. vyd. Praha: ASPI, 2007, s. 342, Komentáře nakladatelství ASPI.

108 WILEY, Lindsay Freeman a Stephen I. VLADECK. Coronavirus, Civil Liberties, and the Courts: The Case Against "Suspending” Judicial Review. Harvard Law Review Forum [online]. 2020, roč. 133, č. 9, s. 195. 
k jejich dosažení. To platí v českém kontextu tím spíše, když se odůvodnění opatření i způsob jejich komunikace řadí $\mathrm{k}$ největším deficitům zdejšího zvládání pandemie. ${ }^{109}$ Tyto závěry představují ostatně nosné důvody zmiňovaného nálezu o zavření maloobchodů. ${ }^{110}$

\subsection{Větší legitimita opatření}

S odůvodněním a legislativně-technicky kvalitními opatřeními úzce souvisí legitimita vládních kroků. Důvěra ve vládu a v její opatření ztělesňuje velmi důležitý určovatel toho, zda občané opatření skutečně a z vlastní vůle dodržuji. ${ }^{111}$ To je velmi důležité vzhledem k povaze této krizové situace, jejîž zvládání závisí na striktním chování se v souladu nařízeními. Maerz a kol. ve svém výzkumu poukazují na neexistenci často zmiňované korelace mezi vládou pevné ruky a zvládání pandemie. ${ }^{112}$ Bargain a Aminjonov naopak tuto korelaci nacházejí mezi vládami s větší důvěrou občanů. ${ }^{113} \mathrm{Ne}$ nadarmo tak německý virolog Hans-Georg Kräusslich tvrdí, že ,pravdèpodobnè nejsilnèjš̌ stránka Némecka prri zuládáni pandemie je racionální tvorba rozhodnuti na nejvy šsi úrovni ve spojeni s vysokou divèrou občanu ve vládu. " a v její opatření se prìtom úzce pojí s její legitimitou, a tedy i s legitimitou jejích opatření.

Úloha soudů ve zvýšení legitimity opatření spočívá už v zlepšení kvality a odůvodnění, jak bylo objasněno v předchozím bodě, zároveň ale taky v jejich specifické společenské roli nezávislého a nestranného arbitra. ${ }^{115}$ Bude-li určité sporné opatření přezkoumáno nezávislým a nestranným arbitrem, který se navíc v České republice těší dlouhodobě největší důvěry v rámci politického systému, ${ }^{116}$ takové opatření zákonitě v prŕpadě pozitivního dobrozdání soudu nabude vyšší legitimity. ${ }^{117}$ Překonání

109 WINTR, Jan. K ústavnosti a zákonnosti protiepidemických opatření na jaře 2020. Správní právo, 2020, roč. LIII, č. 5-6, s. 295.

110 Nález ÚS ze dne 9. 2. 2021, sp. zn. Pl. ÚS 106/20, bod 94.

111 BARGAIN, Olivier a Ulugbek AMINJONOV. Trust and Compliance to Public Health Policies in Times of COVID-19. Journal of Public Economics [online]. 2020, roč. 192, s. 12. DOI: https://www.doi.org/10.1016/j. jpubeco.2020.104316; Srov. taky Nález ÚS ze dne 9. 2. 2021, sp. zn. Pl. ÚS 106/20, bod 94.

112 MAERZ, Seraphine F. et al. Worth the Sacrifice? Illiberal and Authoritarian Practices during Covid-19. $V$-Dem Working Paper 110 [online]. 2020 [cit. 5. 2. 2021]. Autoři zde podrobně popisují metodu výzkumu.

113 BARGAIN, Olivier a Ulugbek AMINJONOV. Trust and Compliance to Public Health Policies in Times of COVID-19. Journal of Public Economics [online]. 2020, roč. 192, s. 13.

114 BENHOLD, Katrin. A German Exception? Why the Country's Coronavirus Death Rate Is Low - The New York Times. New York Times [online]. zima 2020 [cit. 4. 2. 2021]. Získáno z: https://www.nytimes. com/2020/04/04/world/europe/germany-coronavirus-death-rate.html

115 Viz výše a srov. SHAPIRO, Martin M. Courts: a comparative and political analysis. Paperback edition. Chicago: University of Chicago Press, 1986, kap. 1.

116 Viz např. průzkumy veřejného mínění CVVM z července 2021, září 2020 a září 2019 k vybraným institucím veřejného života a k ústavním institucím. Dostupné z: https://cvvm.soc.cas.cz/media/com_form2content/documents/c2/a5446/f9/pi210827.pdf, https://cvvm.soc.cas.cz/media/com_form2content/documents/c2/a5283/f9/pi200925.pdf a https://cvvm.soc.cas.cz/media/com_form2content/ documents/c2/a5307/f9/po201021.pdf

117 Srov. PETROV, Jan. The COVID-19 Emergency in the Age of executive Aggrandizement: What Role for Legislative and Judicial Checks? The Theory and Practice of Legislation [online]. 2020, roč. 8, č. 1-2, s. 80. 
každé další institucionální překážky legitimitu určitých aktů může jedině zvýšit. Petrov v tomto kontextu upozorňuje na zajímavost z Jihoafrické republiky, kde byla pro nezávislý a nestranný dohled vytvořena pro účely pandemie ad hoc soudní funkce. ${ }^{118}$

Shrnu-li, z těchto negativních i pozitivních důvodů by měl Ústavní soud zaujmout aktivní př́stup (č. 4) a převzít tak svou roli v politickém systému při zvládání pandemie. Takový př́stup povede ke zvýšení efektivity celého procesu zvládání pandemie. Volím přístup č. 4, nikoliv velmi aktivní př́stup č. 5. Ten totiž předně nenaplňuje roli soudů v rámci popsané dělby moci (soudy nedisponují expertízou v oblasti pandemie, aby mohli přezkoumávat vhodnost či potřebnost vyhlášení nouzového stavu) a navíc může prínést i nezamýšlené potíže. To at' už vzhledem k výše popsanému dynamickému modelu role soudů (vyhlášení nouzového stavu celou krizovou situaci obvykle začíná a pojí se tak s nedostatkem informací o hrozbě a jejích dopadech) či vzhledem k možným vedlejším nežádoucím reverzním efektům. David Jenkins totiž na základě rozhodnutí amerického a kanadského nejvyššího soudu a britské Sněmovny lordů upozorňuje, že prŕliš aktivistická pro-lidskoprávní rozhodnutí vyprovokovala ostatní složky moci a vedla k rozšíření pravomocí exekutivy či omezení dopadů soudních rozhodnutí. ${ }^{119}$ Cesta do pekel je dlážděna dobrými úmysly.

Ústavní soud by tak měl přezkoumávat (bude-li k tomu samozřejmě vyzván) meritorně jednotlivá opatření testem proporcionality, beroucím $\mathrm{v}$ potaz specifika pandemie (viz výše dynamický model přezkumu související se stavem vědeckého poznánî). ${ }^{120}$ Měl by však posuzovat perspektivou kompetence, procesních požadavků a principů právního státu (včetně vyloučení libovůle) i samotné vyhlášení nouzového stavu. Podobně jako treba soudkyně Tomková se domnívám, že i samotné vyhlášení nouzového stavu může nepřímo zasáhnout do základních práv jednotlivců. Okamžikem vyhlášení nouzového stavu se totiž - nehledě na svěření významných pravomocí do rukou orgánů moci výkonné - např́iklad nemohou konat místní ani krajská referenda, ${ }^{121}$ nebo naopak mohou být zpř́stupněny některé utajované informace podle $\int 60$ zákona o ochraně utajovaných informací. ${ }^{122}$ Ačkoliv souhlasím s Horákem, Dienstbierem a Derkou v tom, že do sféry jednotlivce př́mo zasahují až navazující zákonná ustanovení, ${ }^{123}$ avšak vzhledem k jejich

118 PETROV, Jan. The COVID-19 Emergency in the Age of executive Aggrandizement: What Role for Legislative and Judicial Checks? The Theory and Practice of Legislation [online]. 2020, roč. 8, č. 1-2, s. 80.

119 JENKINS, David. When Good Cases Go Bad: Unintended Consequences of Rights-Friendly Judgments In: DAVIS, Fergal F. a Fiona de LONDRAS (eds.). Critical Debates on Counter-Terrorism Judicial Review. Cambridge, United Kingdom: Cambridge University Press, 2014, s. 91.

120 Tím však rozhodně neříkám, že by se přezkumu opatření měl věnovat pouze Ústavní soud namísto obecných soudů. Naopak, nicméně odvisí to vždy od povahy konkrétního právního aktu.

121 \5 odst. 2 písm. b) zákona č. 22/2004 Sb., o místním referendu.

122 Zákon č. 412/2005 Sb., o utajovaných informacích a o bezpečnostní způsobilosti.

123 HORÁK, Filip, Jakub DIENSTBIER a Viktor DERKA. Právní úprava mimořádného vládnutí v kontextu pandemie covid-19. Rozhodnutí o vyhlášení nouzového stavu. Právník, 2021, roč. 160, č. 6. 
bezprostřednímu navázání na nouzový stav (není třeba dalšího aktu, následky nastupují okamžikem vyhlášení nouzového stavu) je nutno zde soudnímu přezkumu podrobit již samotné vyhlášení nouzového stavu. Takový přezkum by měl být plný, Horákem, Dienstbierem a Derkou navrhovaný „kalkul vad“124 se mi zdá problematický zejména kvưli nejasné hranici mezi zjevnými i nezjevnými vadami. Co je kryto „kalkulem vad“, by měl v prŕpadě pochybností (ztělesněné návrhem některého z kvalifikovaných navrhovatelů) posoudit Ústavní soud. Podobně to z důvodu zachování právní jistoty platí u aktů, které zmiňovaní tři autoři považují za nicotné (vyhlášené neoprávněným subjektem či bez materiální a formální publikace). ${ }^{125}$

Vzhledem k tomu, že vláda je legitimizována prostřednictvím důvěry Poslanecké sněmovny (nutná alespoň tichá podpora většiny Sněmovny) a vzájemná provázanost je tak zřejmá, nelze považovat kontrolu Sněmovnou za dostatečně efektivní. Vláda nebude mít, nedojde-li k nějakému rozkolu mezi vládní koalicí či podporujícími subjekty, problém nouzový stav či jeho pokračování schválit (nezrušit) a parlamentní kontrola se tak redukuje pouze na diskuzní rovinu. ${ }^{126}$ Vláda navíc fakticky může nouzový stav vyhlásit i navzdory nevoli Poslanecké sněmovny, i když patrně půjde o protiústavní postup. To se ostatně v průběhu března 2021 také stalo. ${ }^{127} \mathrm{~V}$ takovém př́ípadě zůstává ustavení mimořádného právního rámce, na nějž jsou navázána jednotlivá opatření zasahující do základních práv, prakticky mimo kontrolu (zůstává pouze vyjádření nedůvěry parlamentem). Vzdáním se veškeré kontroly ve prospěch Parlamentu proto Ústavní soud neučinil chvályhodný krok ve smyslu zdržení se ingerence do zákonodárné moci, ale naopak odepřel svůj nenahraditelný podíl na plnění společného cíle státu. ${ }^{128}$

Potenciálně nebezpečné by také mohlo být absolutní vzdání se kontroly ve prospěch obecných soudů a naprosté vyprázdnění institutu podstatného přesahu vlastního zájmu stěžovatele, představujícího výjimku z principu subsidiarity. ${ }^{129}$ Nehledě na potenciální nutnost rychlého zásahu se může stát, že vlády záměrně i nezáměrně pandemickými opatřeními zastaví běžné fungování obecného soudnictví. To hrozí at' už v rovině samotných soudů a soudních jednáni či v rovině př́stupu k soudu (např. mohou být povolena pouze zcela neodkladná jednánî). K takovému „zmrazení“ fungování obecných soudů

\footnotetext{
124 Ibid.

125 Ibid.

126 Srov. GUASTI, Petra. The Impact of the COVID-19 Pandemic in Central and Eastern Europe: The Rise of Autocracy and Democratic Resilience. Democratic Theory [online]. 2020, roč. 7, č. 2.

127 Srov. např. Kysela: Prodloužit nouzový stav je protiústavní, opřené o zlý úmysl a hejtmani se staví nad sněmovnu. Ceský roz̧blas Plus [online]. 15. 2. 2021 [cit. 30. 3. 2021]. Dostupné z: https://plus.rozhlas. cz/kysela-prodlouzit-nouzovy-stav-je-protiustavni-oprene-o-zly-umysl-a-hejtmani-se-8426921

128 Viz výše a srov. BARBER, Nicholas William. The Principles of Constitutionalism. Oxford, United Kingdom: Oxford University Press, 2018, s. 56.

129 S 75 odst. 2 písm. a) ZÚS.
} 
došlo $\mathrm{v}$ různé míre $\mathrm{v}$ Itálii, Rumunsku nebo Rusku ${ }^{130}$ a takřka absolutním způsobem v Mad'arsku. ${ }^{131}$ Bude-li zásadně omezen př́istup $\mathrm{k}$ soudu, reálnou změnu může přinést pouze přezkum Ústavního soudu. To samozřejmě nevylučuje to, aby přri zachování efektivní možnosti přezkumu obecnými soudy byla vždy subsidiarita ústavního soudnictví respektována. ${ }^{132}$

Vyvažování práv na zdraví a bezpečnost s ostatními základními právy představovalo vždy extrémně složitou otázku pro politickou i soudní složku moci. ${ }^{133}$ Avšak jak píše Jan Wintr: „Chce-li být Ceská republika demokratickým právním státem založeným na úctě k práviom člověka a ob̌́ana, mèla by lidem a občanuim ukládat povinnosti prostřednictvím zákonných, srozumitelných, veřejnè diskutovaných, rádně odìvodnèných a soudně kontrolovatelných aktů, které jsou v souladu s Listinou základních práv a svobod. " ${ }^{134} \mathrm{~K}$ tomu všemu, jak argumentuji v tomto článku, může (mimo jiné) přispět aktivní př́stup Ústavního soudu.

\section{Závěr}

V tomto článku představuji podle mého nejlepší možnou roli Ústavního soudu při pandemii covidu-19, zejména během nouzového stavu. Argumentuji pro aktivní prístup, který spočívá v tom, že by Ústavní soud měl přezkoumávat meritorně jednotlivá vládní opatření, a to prostrednictvím testu proporcionality beroucího $\mathrm{v}$ potaz specifika pandemie, a přezkoumávat by měl také samotné vyhlášení nouzového stavu, avšak to pouze perspektivou kompetence, procesních požadavků a principů právního státu, včetně vyloučení libovůle. Ústavní soud takovým př́stupem totiž potenciálně zabrání zneužití moci, přispěje ke zkvalitnění opatření a jejich komunikace a přispěje také k větší legitimitě opatření.

Pouze společný postup všech tří mocí za společným cílem, jenž definuji jako zastavení šíření nakažlivé nemoci při současném co nejmírnějším dopadu na ekonomiku, stejně jako na základní lidská práva, totiž může v demokratickém právním státě vést k nejefektivnějším opatřením. ${ }^{135}$ Tyto závěry vychází z tezí pozitivního konstitucionalismu a jeho pohledu na dělbu moci.

130 GROGAN, Joelle. States of Emergency. Verfassungsblog [online]. 26. 5. 2020 [cit. 31.1. 2021]. Dostupné z: https://verfassungsblog.de/states-of-emergency/

131 KOVÁCS, Kriszta. Hungary's Orbánistan: A Complete Arsenal of Emergency Powers. Verfassungsblog [online] [cit. 8. 2. 2021]. Dostupné z: https://verfassungsblog.de/hungarys-orbanistan-a-complete-arsenal-of-emergency-powers/

132 Mimo nouzový stav tuto situaci nově řeší tzv. pandemický zákon (zákon č. 94/2021 Sb.), podle nějž k přezkumu celostátních opatření vydaných ministerstvem rozhoduje Nejvyšší správní soud. Návrhy má navíc projednat přednostně (srov. \13 cit. zákona).

133 BARAK, Aharon. The Judge in a Democracy. B.m.: Princeton University Press, 2006, s. 283.

134 WINTR, Jan. K ústavnosti a zákonnosti protiepidemických opatření na jaře 2020. Správní právo, 2020, roč. LIII, č. 5-6, s. 288.

135 Srov. PETROV, Jan. The COVID-19 Emergency in the Age of executive Aggrandizement: What Role for Legislative and Judicial Checks? The Theory and Practice of Legislation [online]. 2020, roč. 8, č. 1-2, s. 81. 